\title{
Effect of physiological stage and nutritional management on some serum metabolite concentrations in Assaf ovine breed
}

\section{Summary}

The Assaf breed represents a small percentage of the total dairy ovine census in the Castilla-León region and there are no studies conducted solely on this breed for understanding their physiology, nutritional requirements, diseases, management and appropiate breeding methods. The aim of the present report is to evaluate and to effects on the nutritional management developed in a flock of Assaf ewes, studying the On the different physiological conditions (Anoestrus, Pregnancy and Lactation). On the other hand, the effect of litter size was also recorded. The study was conducted on thirty-five ewes of the groups, the latter divided into singe management system and randomly assigned to experimental and control conditions and the animals were housed in the same environmental conditions, and received the same diet. The metabolic parameters measured were serum glucose, cholesterol, triglycerides and NEFA. Our results demostrate that it is important to consider two critical moments: firstly, the early pregnancy period, where the administration of a maintenance diet based on low-energy foods (alfalfa hay) is not enough for energy demands, as was shown by the significant decrease in glucose and triglyceride values; and secondly, late pregnancy, where excessive concentrate intake must be avoided in order to prevent future by nutritionases and obesity. It has been observed that serum glucose and NEFA values are influenced more by nutritional management than by physiological conditions.

Key words: ewe, nutrition, physiological status, metabolism

\section{Zusammenfassung}

Titel der Arbeit: Auswirkungen des Reproduktions- und Laktationsstadiums und des Futterungsmanagements auf einzelne Stoffwechselparameter bel Assaf-Schafen

Bislang gibt es noch keine gezielten Untersuchungen über die Bereiche: Physiologie, Ernăhrungsbedarf, Krankheit, Management und adäquate Zuchtmethoden bei Schafen der Rasse „Assaf“. Einer Rasse, welche nur einen kleinen Prozentsatz der gesamten Schafpopulation in der Region Castilla-Léon umfaßt. Ziel der vorliegenden Untersuchungen war es deshalb, das Fütterungsmanagement, welches für eine Herde Assaf-Mutterschafe entwickelt wurde, unter Praxisbedingungen zu überprüfen und zu bewerten. Berücksichtigt wurden dabei insbesondere die Auswirkungen auf den Energiestoffwechsel während verschiedener physiologischer Zustände (Anöstrus, Trăchtigkeit und Laktation). Daruber hinaus wurde der Einfluß der Lämmerzahl registriert. Die Studie wurde an 35 Mutterschafen der Rasse Assaf unter Intensivhaltungsbedingungen durchgeführt, wobei diese zufallig entweder der Versuchs- oder Kontrollgruppe zugeteilt wurden. Innerhalb der Kontrollgruppe erfolgte wiederum eine Unterteilung in Einlinge und Zwillinge. Alle Tiere wurden unter den selben Bedingungen gehalten und erhielten die gleiche Fütterung. Im Serum wurden folgende Stoffwechselparameter bestimmt: Glukose, Cholesterin, Triglyzeride und freie Fettsăuren (NEFA). Wie aus den Ergebnissen hervorgeht, müssen insbesondere die folgenden zwei kritischen Phasen berücksichtigt werden: Erstens die Frühphase der Trächtigkeit, wăhrend der das Angebot einer Ration auf der Basis von Futtermitteln mit geringen Energiegehalt (Luzerne) nicht ausreicht, um den Energiebedarf zu decken, was sich in einem signifikanten Abfall der Glukose- und Triglyzeridwerte manifestiert. Zweitens das späte Trächtigkeitsstadium, in dem eine übermäßige Kraftfutteraufnahme zu vermeiden ist, um nachfolgenden Stoffwechselstörungen und einer Verfettung vorzubeugen. Es zeigte sich, daß die Glukose- und NEFA-Gehalte im Serum mehr durch das Fütterungsmanagement als durch den je-
weiligen physiologischen Zustand beeinflußt wurden. 
Introduction

In Spain, milking ewes production is characterized by two factors: its poor quantitative importance if it is compared with bovine and porcine production and its irregular development in the last 30 years (DAZA, 1997). Since 1980 there has been an increase in the milk ewe industry, helped by the access of Spain to the European Union. Nowadays there exists a new concept about this enterprise in that it has become one of the few ways left for young people to get into farming; in this sense we must consider the help that the absence of a milk ewe quota implies (BUXADE, 1997).

66 per cent of milk ewe production in Spain is located in the Castilla-León region in central Spain. In the development of this industry an important role was played by the imported breeds, like the Assaf. The need to intensify sheep production to conform to today's systems of concentrated farming and to make sheep-breeding more economically rewarding required the use of prolific sheep to increase returns per unit of production (FAHMY, 1996). Many researchers realized that it was faster, easier and more cost-effective to improve sheep production by incorporating prolificacy from imported breeds, using local base populations, than by selecting these populations. In this context, in 1977, 1978 and 1979 our country imported 100 Assaf rams from Israel for crossbreeding with the native Spanish breeds Castellana, Churra and Lacha, seeking to improve their prolificacy and thus, sheep production. The Assaf breed has adapted well to Spanish conditions, although living under intensive management systems (DAZA, 1997).

But the Assaf breed represents a small percentage of the total dairy ovine census in Castilla-León region and there are no studies conducted solely on this breed for understanding their physiology, nutritional requirements, diseases, management and appropiate breeding methods. We know that nutritional management may vary between flocks although in the Castilla-León region we have found that many ovine flocks present a similar nutritional program (locally grown feed represents the main component of the diet), independently of the ovine breed and their productions. We think that this is a mistake, at least in relation to the Assaf breed because it presents a peculiar nutritional requirements based on their milk production, quite different in comparison to other native breeds like Churra or Manchega. The aim of the present report is to evaluate and to comment, in field conditions on, the nutritional management developed in a flock of Assaf ewes, studying the effects on energy metabolism during different physiological conditions, and not to establish a nutritional program. On the other hand, the prolificacy that characterizes this breed is well known, thus the effect of litter size was also recorded.

Materials and Methods

Animals

The study was conducted on a flock located in Valladolid, in central Spain. Thirty-five ewes of the Assaf breed, ranging from 3 to 6 years of age, and of an average weight of $60 \mathrm{Kg}$, were selected. The animals were housed in an intensive management system. 
The animals were randomly assigned to 2 groups: the experimental group $(n=25)$ comprised those that were going to become pregnant and lactate during the experiment, and the control group comprised 10 non-pregnant animals. The experimental ewes were synchronized in anoestrus, using a standard technique (BRITT, 1989). All the animals were housed in the same environmental conditions, and received the same diet. Pregnancy was diagnosed in the second month after synchronization by ultrasound scanning, establishing at this moment two groups: single $(n=11)$ and twin pregnancies $(n=14)$.

Body condition score was assessed by the physical characteristics in the lumbar region, and around the backbone and in the area immediately behind the first rib, as described by RUSSEL et al. (1969) and BOCQUIER et al. (1988).

The mean milk composition of this breed in the flock was as follows: fat: $7.5 \%$; protein: $4.88 \%$ and lactose: $4.74 \%$, showing adequate levels in fat and lactose percentages and lower in proteins, in relation with references (DAZA, 1997).

\section{Diet}

The diet of these animals was the typical used in many flocks of the Castilla-León region and adjusted to maintain the requirements established for pregnancy and lactation of the native breeds (BOCQUIER et al., 1988; BERTONI, 1995). The nutritional protocol was divided as follows:

1. Diet for the dry period (from anoestrus until 3rd. month of pregnancy), established in order to maintain the body condition score. The diet comprised alfalfa hay and trace element and vitamin supplement (Baymix, Bayer $($ ) in a dose of $20 \mathrm{~g} / \mathrm{Kg} \mathrm{DM}$. On the 75 th day of pregnancy the progressive incorporation of the specific pregnancy diet began.

2. Diet for the late-pregnancy requirements, from 3rd. month until parturition. This new diet was composed of mixed forage (alfalfa and ryegrass), concentrate (corn silage, soybean meal and sunflower meal) and the abovementioned mineral and vitamin supplement.

3. After delivery, and until 10 days after parturition, the concentrate in this diet was supressed and the animals were maintained solely on forage.

4. 10 days after parturition we began the progressive incorporation of the lactation diet. It was composed of corn silage and soybean meal, alfalfa hay and vitamin and mineral supplement.

The diet was offered in two equal meals at 9.30 and 18.30 and there were no refusals. The different ingredients were mixed into an "all in one" diet, using an unifeed mixer. Water was available for the ewes at all times.

\section{Sample collection and analyses:}

Blood samples were taken from selected ewes between 8.00 and 9.30 prior to the morning feeding. Sampling began in the anoestrus period, when synchronization was induced, considering it as the baseline sample. The following samples were taken on 
the 75th day of pregnancy, when diet change began; on the 90th day of pregnancy, when the late-pregnancy diet was completely incorporated; 10 days before and after parturition; and, finally one month after parturition (lactation).

Blood samples were collected by jugular venipuncture. Serum was used to measure glucose, cholesterol, triglycerides and non-esterified fatty acids (NEFA). The determinations were carried out using standardized techniques supplied by BioMerieux Laboratories (NEFA procedure) and Knickerbocker Laboratories (Cromatest Reagents() for all other parameters.

\section{Statistical procedure}

The reported values are mean \pm std. error. A statistical test was performed using a twoway analysis of variance to check the influence of physiological status and litter size on the blood parameters. The statistical differences were established taking into account a $\mathrm{P}<0.05$ (WILLIAMS, 1994).

\section{Results}

Developmental changes in the different metabolic parameters in both experimental and non-pregnant ewes, and the significance levels appreciated between pregnant and control groups during the experience are reflected in Table 1. Table 2 shows the mean values ( $\mu \pm$ std. error) in ewes carrying singles and twins.

By way of summary and taking into account the first Table, it is important to observe the significant decrease in glucose concentrations that appear at $90 \mathrm{~d}$ pregnancy in both pregnant and control groups, with a notable recovery in late gestation. After lambing, lactating ewes maintain a progressive increase. In relation to cholesterol values, we wish to point out the significant decrease in pregnant females in late gestation, reaching the lowest concentrations 10 days after parturition. In lactation both groups show different behaviours. Triglyceride values show a significant decrease at $90 \mathrm{~d}$ in pregnant females, although their levels rise in late gestation. It is also important to observe the difference in evolution between these groups in lactation. Finally, NEFA concentrations show a significant increase in the last days of the pregnancy period, in both control and pregnant groups, decreasing progressively after this moment. During the study period both groups showed the same evolution.

Considering the differences between these groups during the experiment (Table 1) the statistical differences $(\mathrm{P}<0.05)$ appeared at $90 \mathrm{~d}$ pregnancy in cholesterol and triglyceride values; in late pregnancy (10 days before parturition) in NEFA concentrations; at the onset of lactation in glucose values; and finally, during lactation, but only in triglyceride concentrations.

Lastly, considering the influence of litter size on the studied parameters (Table 2), it can be seen that the number of fetuses that the female carries has no influence on glucose evolution; on the other hand, the beginning of pregnancy determines modifications in triglyceride values, twins being the group with lower concentrations. Finally, the end of pregnancy is an important moment as regards cholesterol and 
Table 1 Mean values ( $\mu \pm$ std. error) of the different metabolic parameters in control and pregnant ewes during the different phases of the study (Mittelwerte ( $\overline{\mathrm{x}} \pm \mathrm{s}$ ) verschiedener
Stoffwechselparameter bei Kontrollschafen und trächtigen Schafen während verschiedener Phasen der Studie und ermittelte Signifikanzniveaus beim Vergleich zwischen
Kontrollschafen und trächtigen Schafen im Untersuchungszeitraum)

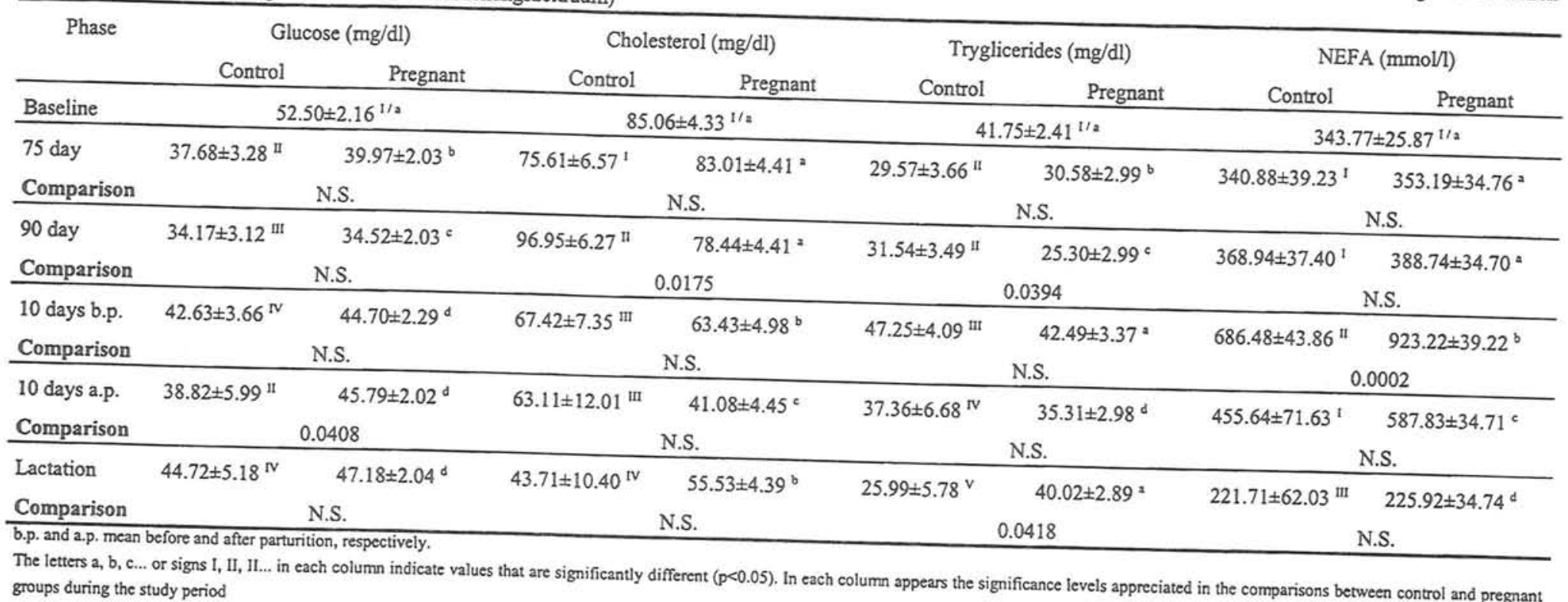


Table 2

Mean values ( $\mu \pm$ std. error) of the different metabolic parameters in twins and single bearing ewes. There are represented the significance level when we analized the effect of litter size (Mittelwerte $(\overline{\mathrm{X}} \pm \mathrm{s})$ verschiedener Stoffwechselparameter bei Mutterschafen mit Einlingen und Zwillingen. Bezüglich der Auswirkungen der Nachkommenanzahl ist das Signifikanzniveau angegeben)

\begin{tabular}{|c|c|c|c|c|c|c|}
\hline Parameter & Group & $75 \mathrm{~d}$ pregnancy & 90 d pregnancy & 10 days b.p. & 10 days a.p. & Lactation \\
\hline Glucose & Single & $41.33 \pm 3.28$ & $37.57 \pm 3.28$ & $44.94 \pm 3.60$ & $46.73 \pm 3.04$ & $46.77 \pm 3.04$ \\
\hline \multirow[t]{2}{*}{ (mg/dl) } & Twin & $38.94 \pm 3.45$ & $32.24 \pm 3.45$ & $44.50 \pm 3.99$ & $44.86 \pm 3.69$ & $47.59 \pm 3.69$ \\
\hline & & N.S. & N.S. & N.S. & N.S. & N.S. \\
\hline Cholesterol & Single & $84.09 \pm 7.14$ & $76.11 \pm 7.14$ & $72.67 \pm 7.82$ & $44.57 \pm 6.61$ & $55.90 \pm 6.61$ \\
\hline \multirow[t]{2}{*}{$(\mathrm{mg} / \mathrm{dl})$} & Twin & $82.20 \pm 5.35$ & $80.19 \pm 5.35$ & $55.73 \pm 6.18$ & $37.60 \pm 5.72$ & $55.16 \pm 5.72$ \\
\hline & & N.S. & N.S. & $P>F=0.0494$ & N.S. & N.S. \\
\hline Trygliceri- & Single & $37.60 \pm 4.45$ & $24.76 \pm 4.45$ & $39.03 \pm 4.88$ & $39.13 \pm 4.12$ & $38.43 \pm 4.12$ \\
\hline des & Twin & $25.31 \pm 3.70$ & $25.70 \pm 3.70$ & $45.38 \pm 4.28$ & $31.49 \pm 3.96$ & $41.60 \pm 3.96$ \\
\hline$(\mathrm{mg} / \mathrm{dl})$ & & $\mathrm{P}>\mathrm{F}=0.0431$ & N.S. & N.S. & N.S. & N.S. \\
\hline NEFA & Single & $340.27 \pm 54.55$ & $402.07 \pm 54.05$ & $828.63 \pm 59.75$ & $542.85 \pm 50.50$ & $204.54 \pm 50.51$ \\
\hline \multirow[t]{2}{*}{$(\mathrm{mmol} / \mathrm{l})$} & Twin & $362.88 \pm 43.28$ & $378.75 \pm 43.28$ & $1002.04 \pm 49.98$ & $632.82 \pm 46.27$ & $247.31 \pm 46.20$ \\
\hline & & N.S. & N.S. & $\mathrm{P}>\mathrm{F}=0.0288$ & N.S. & N.S. \\
\hline
\end{tabular}

b.p. and a.p. mean before and after parturition, respectively.

NEFA. It can be observed that twin-bearing ewes show lower concentrations in cholesterol and higher values in NEFA than singles.

Finally, considering the body score condition (BSC), the values during the experiment were within the optimal condition considered by BOCQUIER et al. (1988), and around 3.0 , with one exception: in late gestation, with a mean value above 3.5 .

\section{Discussion}

It is well-known that alfalfa hay provides the animal with low energy, due to its poor levels of lipids and glucogenic precursors (McDONALD et al., 1986; AFRC, 1996). This fact explains, in our opinion, the important decrease that all the animals show in glucose and triglyceride values in the early-pregnancy period. In the first case, even lower than physiological values (DESCO et al., 1989; KANEKO, 1989).

At this point it is interesting to discuss the developmental changes that appear in triglyceride values between 75 and $90 \mathrm{~d}$ gestation in the pregnant group. In our opinion they are the result of the pregnancy requirements like placental growth, with a rapid development between 40 and 80 days' gestation (CLARKE et al., 1998). Obviously, this fact implies special needs in pregnant ewes, although less than those characteristic of late pregnancy. For this reason the diet might provide the necessary energy supply. In our case it is not so and the animal must metabolize triglycerides to obtain energy and to produce steroid hormones (like progesterone), necessary to maintain pregnancy (JAINUDEEN and HAFEZ, 1989). We must add that the low glucose levels in these ewes also regulates the direction and rate of adipose tissue metabolism, increasing 
triglyceride metabolization (CLARENBURG, 1992). If we take into account litter size, it appears that twins show this metabolic evolution earlier than singles, which explains their lower values, according to previous reports (FREETLY and FERREL, 1997).

In our opinion, the results in late gestation are an important reflection on dietary supply. We know that the energy requirements of ewes increase 50 to $120 \%$ over maintenance at the end of this period, depending on litter size (NRC, 1985). The diet of these animals in this period was composed of energy-enriched foods (MCDONALD et al., 1986; PALMQUIST, 1997) contributing to the energy supply and thus the recovery of glucose, triglyceride and NEFA values in both groups. In this sense it is important to consider the influence of maize, rich in starch (glucogenic precursor). A maize supply implies an increase in whole-body glucose tumover (WEEKES, 1991) explaining that control and pregnant ewes show the same evolution. These results are in accordance with the observations made by ODOHERTY and CROSBY (1998) who find a positive correlation between plasma glucose and metabolizable energy intake. The absence of significant influence of physiological condition on glucose values has been also described in previous reports in sheep (BICKHARDT et al., 1988; ALONSO et al., 1997). It seems that nutritional management is the factor that controls this parameter.

Nevertheless, cholesterol and NEFA values are greatly influenced by pregnancy in the same period. With respect to the first parameter, the differences are evident at $90 \mathrm{~d}$ gestation, according not only to the increase in secretion of steroid hormones but also the transfer into the fetus (TAINTURIER, 1984; EDQVIST and STABENFELDT, 1989). This appears to be more acute in twin-bearing ewes. McNEILL et al. (1998) give us an explanation for this evolution in that they find higher progesterone levels in this group in comparison with singles. On the other hand, NEFA values on blood have been considered as a sensitive clinical index of fat mobilization (BARTLEY, 1989) and an indirect measure of feed intake in housed animals (FOX et al., 1991). In our study the last idea must be applied because of serum glucose behavior, which indicates that the animals, and especially pregnant ewes, received an adequate energy supply. But the statistical differences found 10 days before lambing can only be understood by considering the influence of physiological status. HERDT (1988) explained that in late gestation, and in healthy animals, endocrine changes that occur promote gluconeogenesis, ketogenesis and fatty acids mobilisation owing to the alteration in the ratio of insulin to glucagon. In addition, the synthesis of progesterone demands NEFA mobilisation for acetate synthesis in liver (JAINUDEEN and HAFEZ, 1989) and finally, there is a reduced insulin responsiveness in late gestation compared with nonpregnancy or lactation (SCHLUMBOUM et al., 1997) which implies a lack of the ability to utilize glucose in periferic tissues, causing fatty acids levels to rise. Taking into account the total of animals, it is obvious that they received an excess of energy, a very common fact in sheep that receive little exercise and large amounts of palatable foods. This can generate an overweight condition associated with health problems that arise during late gestation, parturition and early lactation (DONOGHUE and KRONFELD, 1990). In our study, although the BCS rose, the ewes did not show clinical signs of metabolic disease, although in our opinion this diet for late pregnancy 
must be modified in concentrate content in order to avoid future problems like ruminal acidosis. In fact, the mean NEFA values in these animals and at that moment are higher than those recorded as physiological (CLARKE et al., 1998).

After lambing it is well-known that the energy and glucose demands of lactation eclipse those of pregnancy, as pointed out by HERDT in 1988, and in our opinion is the main cause of the different evolution appreciated in control and experimental groups. The deletion of concentrate in the first 10 days produces a decrease in the energy supply and so lower levels of cholesterol, triglyceride and NEFA values in comparison with previous stages. But there is an exception: glucose evolution in suckling ewes. We can consider two main reasons for this increase: milk production, which implies glucose mobilisation for lactose production (McNEILL et al., 1998) and the increase in feed intake (RUIZ et al., 1997).

The next important changes appeared in lactation, with a recovery in cholesterol and triglyceride values. The close relationship between these two parameters and lactation has been established by many authors, and is related to the diet that the animals receive (DAZA, 1997). We cannot forget that the Assaf ovine breed is a milk producer, and that the fat content in milk is high in relation to other species. This means a mobilization of triglycerides which constitutes over $95 \%$ of milk lipids (BARTLEY, 1989) and cholesterol values, associated with increased lipoprotein synthesis required for lipid transport (KAPPEL et al., 1984). Obviously, lactating ewes present different requirements than non-suckling females. Diet provides the proper energy for this situation, more than in late pregnancy, and as can be seen in NEFA evolution lipid mobilisation is not necessary.

\section{Conclusions}

When we evaluate the nutritional management of this flock there are two critical moments: early pregnancy, where it can be seen that the maintenance diet, based on low-energy foods, is not enough for energy demands, as shown by glucose and triglyceride values; and secondly, late pregnancy, where excessive concentrate intake must be avoided in order to prevent future metabolic diseases and obesity. Serum glucose and NEFA evolution proved to be more influenced by nutritional management than by pregnancy itself.

\section{References}

ALONSO, A.J.; TERESA, R.; GARCIA, M.; GONZALEZ, J.R.; VALLEJO, M.:

The effects of age and reproductive status on serum and blood parameters in Merino breed sheep. J. Vet. Med. A 44 (1997), 223-231

AFRC:

Necesidades energéticas y proteicas de los rumiantes. Ed. Acribia, Spain (1996)

BARTLEY, J.C.:

Lipid Metabolism and its disorders. In J.J. KANEKO (Editor). Clinical Biochemistry of Domestic Animals. 4th. ed. Academic Press, USA (1989) 
BERTONI, G.:

La alimentación de la oveja de leche. Veterinaria en Praxis 10 (1995) 3, 9-13

BICKHARDT, K.; NEUMAN, N.; STEINMANN, C.:

Determination of metabolites of energy metabolism in bioptic liver samples. A contribution to the characterisation of ketosis in sheep. J. Vet. Med. A 35 (1988), 790-799

BOCQUIER, F.; THERIEZ, M.; PRACHE, S.; BRELURUT, A.;

Alimentación de ovinos. In: INRA (Editor), Alimentación de los bovinos, ovinos y caprinos. ed.
Mundi-prensa, Spain (1988), 225-252 BRITT, J.H.:

Inducción y sincronización de la ovulación. In: E.S.E. HAFEZ (Editor), Reproducción e Inseminación BUXADE, C.:

Ovino de leche: Aspectos clave. Ed. Mundi-Prensa, Spain (1997)

CLARENBURG, R:

Physiological Chemistry of Domestic Animals. Mosby, Philadelphia (1992)

CLARKE, L.; HEASMAN, L.; JUNIPER, D.T.; SYMONDS, M.E.:

DAZA, A.: Maternal nutrition in early-mid gestation and placental size in sheep. Br. J. Nutr. 79 (1998), 359-374
A.

Reproducción y sistemas de explotación del ganado ovino. Ed. Mundi-Prensa, Spain (1997).

DESCO, M.; CANO, M.J.; DUARTE, J.; RODRIGUEZ F.; FERNANDEZ D.; ALVAREZ, M.; ANTORANZ,
J.C.; RUBIO M.A.; GARCIA P.; CAÑIZO J.F. Blood biochemistry values of sheep (ovis aries ligeriensis). Comp. Biochem. Physiol. 99/A4 (1989),
$717-719$

DONOGHUE, S.; KRONFELD, D.:

Clinical nutrition of sheep and goats. Vet. Clin. North Am.: Food Anim. Pract., 6 (1990) 3, 563-576

EDQVIST, L.E.; STABENFELDT, G.H.:

Clinical reproductive endocrinology. In J.J. KANEKO (Editor). Clinical Biochemistry of Domestic Animals. 4th. ed. Academic Press, USA (1989).

FAHMY, M.H.:

Prolific Sheep. CAB International, Wallingford, United Kingdom (1996)

FOX, M.T.; GERRELLI, D.; PITT, S.R.; JACOBS, D.E.: The relationship between appetite and plasma nonesterified fatty acid levels in housed calves. Vet. Res.
Comm., 15 (1991), 127-133

FREETLY, H.C.; FERRELL, C.L.:

Oxygen consumption by and blood flow across the portal-drained viscera and liver in pregnant ewes. J.

HERDT, E.H.: Anim. Sci., Albany, N.Y. 75 (1997), 1950-1955

JAINUDEEN, M.R.; HAFEZ, E.S.E.

Gestación, fisiologia prenatal y parto. In: E.S.E. Hafez (Editor), Reproducción e Inseminación Artificial KANEKO, J.J. en Animales Domésticos. $5^{\circ}$ ed., Interamericana, México (1989), 203-224

Appendix. In In J.J. KANEKO (Editor). Clinical Biochemistry of Domestic Animals. 4th. ed. Academic Press, USA (1989)

KAPPEL, L.C.; INGRAHAM, R.H.; MORGAN, E.B.; ZERINGUE, L.; WILSON, D.; BABCOCK, D.K.: Relationship between fertility and blood glucose and cholesterol concentrations in Holstein cows. Am.
J. Vet. Res. 45 (1984) 2, 2607-2613

McDONALD, P.; EWARDS, R.A.; GREENHALGH, J.F.D.: Nutrición Animal. Ed. Acribia, Spain (1986)

McNEILL, D.M.; MURPHY, P.M.; LINDSAY, D.R.: Blood lactose v. milk lactose as a monitor of lactogenesis and calostrum production in Merino ewes. NRC.: Aust. J. Agric. Res. 49 (1998), 581-587

Nutrient requirements of sheep. 6th. ed. National Academic Press, Washington, D.C (1985). 
ODOHERTY, J.V.; CROSBY, T.F.:

Blood metabolite concentrarions in late pregnant ewes as indicators of nutritional status. Anim. Sci. $66 / 3$ (1998), 675-683

PALMQUIST, D.L.:

Utilización de lípidos en dietas de rumiantes. Prod. Anim. 126 (1997), 18-38

RUIZ, M.J.; SILVA, J.H.; DIAZ, I.; ONOFRIO, L.; MACHADO, C.F.:

Variación de algunos parámetros urinarios y hemáticos en ovejas gestantes bajo riesgo de cetosis. Rev. Med. Vet. 78 (1997) 4, 249-256

RUSSEL, A.J.F.; DONEY, J.M.; GUNN, R.G.:

Subjective assessment of body fat in live sheep. J. Agric. Sci., Cambridge 72 (1969), 451-454

SCHLUMBOUM, C.; SPORLEDER, H.P.; GURTLER, H.; HARMEYER, J.:

Effects of insulin on glucose and fat metabolism in ewes during various reproductive states in nomal and hypocalcemia. DTW 104 (1997) 9, 359-365

TAINTURIER, D.:

Variations in blood composition in dairy cows during pregnancy and after calving. Res. Vet. Sci. 37 (1984), 129-131

WEEKES, T.E.C.:

Hormonal control of glucose metabolism. In: T. TSUDA, Y. SASAKI and R. KAWASHIMA (Eds) Physiological aspects of digestion and metabolism in ruminants. Academic Press, USA (1991), 183-200 WILLIAMS, B.:

Biostatistics: Concepts and applications for Biologists. Chapman and Hall, UK (1994)

Received: 19.02 .1999

Accepted: 31.05 .1999

Author's address

Dr. CRISTINA CASTILLO, JOAQUIN HERNANDEZ, MARTA LOPEZ-ALONSO,

MARTA MIRANDA, JOSE LUIS BENEDITO

Universidad de Santiago de Compostela

Facultad de Veterinaria,

Campus de Lugo

Departamento de Patología Animal

27002 LUGO

Spain 